\author{
Viacheslav BLIKHAR ${ }^{1}$ \\ Mariia BLIKHAR ${ }^{2}$ \\ Mykola KOZLOVETS ${ }^{3}$
}

\title{
THE IMPORTANCE OF LEGAL CONVERGENCE IN THE ACTIONS OF THE STATE REGARDING RELATIONS WITH THE CHURCH: A COMPARATIVE APPROACH
}

This paper examines the influence of state authorities on the approval of church-state relations. State power constantly intersects in various levels with church institutions due to the specific nature of its activities. The church and the state cooperate in the development of philosophical and social concepts, specific social programs, and in determining the progress and direction of society. The article demonstrates that anthropocentric ideas of Christianity are of great importance in ensuring the stability and effectiveness of state and church relations. The social and political partnership of the authorities and the church is always built on the reconciliation of mutual interests of the partner entities, and political relationships can take many forms: dialogue, partnership, cooperation, indifference, rivalry, conflict, domination and subordination. The historical forms of state-church relations are characterized through an in-depth analysis of different countries, in particular Russia and Poland, and we outline prospects for further development We argue that the Christian worldview is deeply rooted in the Ukrainian mentality, socio-philosophical space, and state-building processes. An existential interpretation of time is revealed as an important constant in the formation and construction of anthropological and social space. It is especially important to take into account the phenomenon of human rights and the education of citizens. We argue that a society with an awareness of the primacy of an individual over society will reject and oppose totalitarian ideologies. In order to ensure the partnership and stability of public authorities and the church, representatives of the state must promote the implementation of Christian moral-ethical and anthropological ideas and ideals into social practice. By being aware of their calling, government officials can positively influence the development of legal relations in the church dimension of being. Priority area should include the educational, legal, and religious dimension of the existing Ukrainian state.

Keywords: church, state, state-church relations, Christianity, Catholicism, Orthodoxy, Christian outlook, religious organizations.

${ }^{1}$ Viacheslav Blikhar, Doctor of Philosophical Sciences, Professor, Head of the Department of Philosophy and Political Science, Lviv State University of Internal Affairs, Ukraine; e-mail: blikharv@ukr.net (corresponding author). ORCID: 0000-0001-7545-9009.

${ }^{2}$ Mariia Blikhar, Doctor of Juridical Sciences, Docent, Associate Professor at the Department of constitutional and international law, Lviv National University Lviv Polytechnic, Ukraine; e-mail: blikharm@ukr.net. ORCID: 0000-0003-2974-0419.

${ }^{3}$ Mykola Kozlovets, Doctor of Philosophical Sciences, Professor, Professor of the Department of Philosophy and Political Science Zhytomyr Ivan Franko State University, Ukraine; e-mail: mykola.kozlovets@ukr.net. ORCID: 000-0002-5242-912X. 


\section{INTRODUCTION}

Due to the specifics of state authorities' activity, state power constantly intersects in various levels with church institutions. State and church cooperate in the development of philosophical and social concepts, specific social programs, in determining the progress and direction of the society movement. Social and political partnership of the authorities and the church is always built on the reconciliation of the mutual interests of the partner entities, and political relationships can take many forms: dialogue, partnership, cooperation, indifference, rivalry, conflict, domination and subordination.

In the dimension of state-church relations, the forms of interaction between state authorities and Christian churches are based on the Christian worldview, which is deeply rooted in the Ukrainian mentality, socio-philosophical space and state-building processes. It is especially important to take into account the phenomenon of freedom of the person. It the society, in which there is an awareness of the primacy of personality over society will demonstrate a rejection of ideologies of a totalitarian type, will oppose them. It is substantiated that in order to ensure the partnership of public authorities and the church, the stability of state-church relations, the representatives of the state in their existential-worldview must promote the implementation of Christian moral-ethical and anthropological ideas and ideals into the social practice. Aware of their calling, government officials can positively influence the development of legal relations in the church dimension of being. One of the priority areas of their activity is the educational, legal and religious dimension of the existence of the Ukrainian state

\section{LITERATURE REVIEW}

Being at the point of modernity of the spatio-temporal continuum, we do not always realize the factors that played a major role in the formation of the entities of the political and social dimension. Geographically and historically, Ukraine is directly related to Europe, its culture and mentality. In this sense, the words of Monsignor Joseph Dore concerning Europe can be referred to Ukraine with good reason:

The past history of Europe is unthinkable without Christianity, so it follows that the question of the future of Europe itself can neither be posed nor analyzed unless one considers the fact that Christianity itself can still be capable of nourishing it even at a price of quite a significant evolution of it (Dore, 2001).

The Christian worldview is deeply rooted in the Ukrainian mentality, in the sociophilosophical space and state-building processes in the territory of our state. Government bodies that are directly and indirectly influenced by the moral, ethical and anthropological ideals of the Christian worldview, paying attention to this impact have a great prospect in the field of constructive change of Ukrainian society to the social ideal. A society where each of its members will have every opportunity to realize their transcendental-semantic mission in the dimension of earthly being. At the same time, in such a society, each of its members will feel happy about living in it.

It is the anthropocentric nature of the Christian religion that will always determine the direction of government in any country. The very core of this anthropocentrism was expressed by J. Dore, saying that 
every person, regardless of their age and gender, ethnic origin and nationality ... has a heart and a soul, is a person, and therefore deserves all the respect, absolute respect ... even more: according to the Christian faith, the weaker in danger, the more unrecognized and rejected one is, the more honor and respect, help and support one deserves (Dore, 2001).

Christian, even simply universal, anthropological ideals are a kind of beacon for government officials, on which the advancement and direction of society movement usually depend. Due to the specific nature of its activities, the authorities are in a such a position that they must constantly intersect in different planes with different institutions, including the ecclesiastical ones. An interesting aspect of the influence of state power on the activities of church institutions is presented by O. Isaev (Isaiev, 2011). He takes into account the fact that throughout the history of Russia, relations between the state and the Russian Orthodox Church have been one of the main priorities for the functioning of both, moreover, such interaction significantly influenced the characterization of functioning of elements of state and social development. The researcher considered the relations between these institutions at the level of „subject - subject” and defined through the concept of „state - confessional (church) relations”, which are ,a collection of historically evolving and changing forms of interconnections (political, legal, economic, social and cultural) between state institutions and institutional religious entities" (Isaiev, 2011).

In general, relations in the political arena are predominantly dependent on the level of mutual interest and the goals of specific actors involved in these relations. The latter result in various forms: dialogue, partnership, cooperation, indifference, rivalry, conflict, domination and submission. As for the sphere of state-church relations, it can be said that in the long view, considering reaching the ultimate goals, the inherent most democratic and constructive forms are cooperation and partnership. To this state of things both the first and the second institutions came, having overcome a long way of various impasse forms of relationships, which, given the logical continuation, usually led to the realization of their inefficiency, since they always occurred contrary to the main goals of the development of the state authorities and the church institution.

Social and political partnerships between public authorities and the church are always built on the mutual interests of the partner entities. In the development of a variety of both specific social programs and philosophical-social concepts, the contribution of each party to the common cause of the development of close to the social relations ideal is significant. Despite some positive dynamics of the development of such relations for today, O. Isaev also presents the main vectors of their further progress in the perspective of the Russian Federation: 1) improvement of the legal and regulatory framework for cooperation between the authorities and confessions regarding the elaboration of the strategy of the Concept of State Religious Policy; 2) participation in the activity of public chambers, commissions, other consultative structures at the executive bodies of state power; 3) working out at the theoretical and methodological level such forms of interaction as social expertise, social grant and procurement; 4) development and implementation by the parties of the interaction of a single conceptual apparatus: both at the level of household and popular (Isaiev, 2011). It should be noted that the above proposals, in fact, should not differ much in the case of their application in the territory of Ukraine.

The goodwill of government officials is important for building strong partnerships with church representatives. The state as a public institution is called to serve the society in 
general and every person in particular. In view of this, the state is to some extent involved in creating optimal conditions for the functioning of a large social organism. It is also worth emphasizing the need for correlation from those institutions that the state cooperates with. For example, in the dimension of church-state relations the appeal of the leaders of the Christian churches of Ukraine to legislators to introduce new ways of registering individuals in Ukraine can be significant. Such an appeal was a reaction to the appearance of bills „About registration of individuals in Ukraine” and „About the Unified Register of Personal Data", according to which a large amount of information should be collected in the new general register of individuals residing on the territory of Ukraine, which would concern each person. This state of things concerns fundamental human rights and freedoms, among which the right to religion is not the least.

According to these bills, there may be a situation of lifelong fixation for each person of a specific digital code, which will become the main feature of a person, putting aside personal traits. As mentioned in the above message,

In essence, the assignment of an impersonal code to a person that is supposed to be used in all legal relations between the state and the citizen, as well as between the citizens themselves, contradicts the Christian understanding of the meaning of name and in the spiritual and cultural sense breaks the connection of generations (Zvernennia, 2008).

Therefore, a pragmatic approach to using an identification number instead of the traditional attributes of a person in the social dimension, along with the practical benefit, also entails significant dangers in many other dimensions, affecting even the anthropophilosophical dimension of the human personality being. A closer examination of this problem reveals other negative consequences of such an innovation. In particular, there are doubts about the reliability of the protection of the base itself. In addition, there is a probability of criminal use of such a base against people who are objectionable to the authorities and all people in general.

Of course, in a sense, there is a practical benefit of such an innovation, because the control over socially dangerous individuals and phenomena will be much higher, however, the control will also be greater relatively to ordinary law-abiding citizens as well. This fact is likely to lead to a change in the socio-psychological and philosophical-anthropological space of the latter, and obviously not for the better one, but becoming a catalyst for many of the negative social and psychological issues within a country that would dare to implement these bills. Note that even in countries that are actually at high risk of terrorist activity, although respect for the principles of a democratic society is being traced, other means are being sought to control the situation in the country than those which would be characterized by the total accumulation of information regarding their citizens. In the situation of possible danger of prerequisites for the development of a totalitarian regime, the voice of representatives of religious institutions is heard especially clearly and with parental care it warns against a simplified approach to solving social problems by means of total control over the born free human personalities. Addressing the deputies and their fellow citizens, the leaders of the Christian churches of Ukraine call for awareness of this situation not only in sight of pragmatic relative benefits, but also in many other dimensions of human being: 
Remember the responsibility stated in the Constitution of our state to God, to past generations who have passed through to us the spiritual and cultural tradition, surname, name and patronymic, and to future generations who may find themselves in totalitarian slavery, which cannot be exited from in this life (Zvernennia, 2008).

The mentioned example is a significant one, it demonstrates peculiar incompleteness of the decisions made by government that on solving a problem in one dimension, completely overlooks the changes that can occur in other dimensions of human society. In such a situation, one clearly understands the need for a comprehensive and integrative approach where public authorities should at least listen to representatives of other public institutions and simply different professionals, which are relevant to life, in particular, of the human personality and society in general. In addition, in such important matters, it is obligatory to take into account the opinion of experts who, in accordance with their professional responsibilities, deal with the transcendental-axiological level of human being. First of all, this applies to religious figures, professional philosophers and merely sophists. And if the opinion of the first ones, owing to a well-developed administrative and hierarchical church structure that already has some authority in society, is often heard and taken into account, then the scattered voices of others do not have such weight in public space, they mainly rely on the authority of one or another sophist. In this sense, it seems promising to unite such people in an organization to influence society, taking into account the moral, ethical and axiological principles of the transcendental dimension of being.

The state power through its various structures has a real opportunity for direct and indirect influence on the course of social and spiritual life of its citizens. In this sense, the main thing for representatives of state power is the awareness of the importance to build internal public relations on principles that are rooted in the values sphere of life. One example of the phenomenon rooted in the axiological dimension of being may be the phenomenon of Sunday of the Christians or Sabbath of the Jews. At first glance, these phenomena appear to be merely a remnant of past beliefs, a product of a completely different era, after all, representative of the mentality of representatives of the distant past. And as we continue to develop our minds in this direction, we come to the real understanding of Sunday as just a day off that helps to gain strength for a new working week. To some extent, this approach is a reflection of the pragmatic and economic mentality of our time. Adhering to it, the modern man increasingly feels longing for something that would give it a fullness of being, a sense of true life, which would not be limited by the narrow space-time boundaries of its living space. This state of dissatisfaction compels thinking contemporaries to seek what gave our predecessors a sense of fullness of being, that which we lost through the pursuit of improving the material-sensual sphere of life, which resulted in a kind of reduction of human needs, which led to a simplified understanding of the person.

The depth of Sunday's issue is revealed by Johann van der Vloet, quoting R. Guardini in his study:

Sunday is not a matter of an individual person, their religious position or need for rest. This is a community matter, or rather a matter of public order (Vloet, 1994).

Such a significance of the Sunday phenomenon for the social order is based on an understanding of its importance in the anthropological dimension, where Sunday is closely 
linked to human dignity. Since the denial of the deep meaning of Sunday leads to a shallow perception of the human personality, which in this case is reduced to an economically consumer being whose main attributes are the production and consumption of the goods. This perception of man is quite widespread in today's technogenic society, where its value is measured mostly by efficiency in the economic sphere - the more products a person can produce, the more valuable he/she is. Such a way of human perception in the conditions of further development of society will further lead to a threat to human dignity.

It is difficult to disagree with Johann van der Vloet that this state of affairs is a kind of response to a new interpretation of time, which covers the phenomena of how modern men understand their being, and, as a consequence, how they build their living space. Indeed, time in the anthropological-existential dimension is not only a certain period of the physical dimension, but also something much larger. As Johann van der Vloet notes,

time is not only what passes, but also existential experience of the past, present and future in their various relationships, among which the present life develops and plays out (Vloet, 1994).

Consequently, in this case we are dealing with an existential interpretation of time as an important constant in the formation and construction of an internal anthropological and general social space. Understanding this dimension of human interpretation of time is the foundation of responsible governmental activity in building existential social relations, where a person will no longer be considered an odinary, time-influenced object. A person will be that free creator of a peculiar existential-temporal dimension, which will certify its axiological dignity and originality. Whereas, according to the technogenic approach to a person people not only lose their physical and mental health, but also become in fact a kind of hostage to work.

\section{RESULTS AND DISCUSSIONS}

Relations between public authorities and citizens almost always contain an element of violence, since the state is mostly seeking the stability and prosperity that are possible in the absence of conflict between people. However, in this sense, each person seeks something else, namely, activity and diversity. In this perspective, it is possible to understand the idea that government measures weaken the energy of the people. As Wilhelm von Humboldt notes regarding the way the state teaches its citizens,

the actions which the state deems best, it submits as a result of its research and then either straightforwardly prescribes citizens to comply with them by adopting a specific law or indirectly makes them compulsory for citizens, by pursuing some measures, or by encouraging them, relying on their authority, giving certain rewards, resorting to other means of encouragement, or, finally, or simply recommends them to be carried out, giving reasoned reasons (Humboldt, 2009).

In other words, the state finds, in their opinion, the ,right” solution and tries in various ways to make it implemented by citizens. Of course, there is a positive thing in this state of things, because they achieve an important goal - the stability of society. However, there are many negative aspects. There is no guarantee that decisions made by the state are correct in a moral and ethical perspective, and this further calls into question the observance of 
fundamental human rights. There are many examples of such a false approach in the history of mankind - from the 1 iniquities and cruelty of ancient empires to the terrible experiments on humanity of totalitarian systems close in time to us.

With regard to the attitude of state authorities to citizens, even at the universal level of humanity it is important to take into account the phenomenon of freedom of the human personality. An ideal one in this sense would be an approach similar to that of V. von Humboldt: the best instruction should be manifested as

demonstrate to a person all possible solutions to the problem, thus preparing the person for the independent choice of the most appropriate solution; or, much better, let a person find their own solution, telling in detail about all the difficulties that must be overcome (Humboldt, 2009).

Of course, this would be an ideal approach to human freedom. However, it is not always possible to apply this approach to ,state-individual” relationship, given the uneven development of the intellectual and moral-ethical qualities of the individual. Thus, professional experts should develop optimal decisions in power circles, and only then, with wise leadership, should serve as an ideal for the entire community. In this sense, the words of V. Parsons are quite successful saying that

where there is clearly centralized power, there is an expert - sometimes in sight, sometimes in shadow; in agreement with the justification of the government or in the work on its change ... this expert stands with one foot in knowledge and the other in power and prepares secrets for practical use (Parsons, 2006).

Therefore, great responsibility lies with the ideological leaders of various political systems, since the system itself is like a machine blindly controlled by its leaders, which materializes the thoughts of its leaders (Blikhar, 2013).

Together with the complementary function of the church in the society management, the authorities themselves must limit the non-church factors to some extent. Since one of the key tasks of the government is the protection of natural human rights, in particular the right to liberty, one of the main tasks of the government should be to protect the freedom of its citizens both from encroachment from outside and from internal dangers on the part of their countrymen. That is why the government should take care of law enforcement, promote and protect market competition, and support the private sector in all areas of public life. A well-developed private sector can be a kind of guarantor against the arbitrariness of a centralized government, both in the economic and purely ideological fields - it can be a very effective defense of the right to free speech, beliefs and, finally, religion.

Thus, V. von Humboldt, writing about two types of education of the citizens of the state, distinguishes, on the one hand, training as a form of restriction of the rights of the state, and on the other - training as a form of trust in its citizens:

When it comes to adults, only the negative way can be adhered to, giving them complete freedom, which does not remove any obstacles and at the same time generates the strength and the skills needed to overcome them; and a positive way is only possible when it comes to children and youth covered by a truly national public education system (Humboldt, 2009). 
No one has any doubts about the need to use a variety of methods in raising children. In fact, public authorities have great opportunities to help children learn about the essence of the Christian faith. Indee, unlike adults working in different places, children are almost $100 \%$ likely to attend educational institutions. This very fact enables the state to reach almost all the representatives of this age group through educational institutions.

D. Sutton, for example, cites the results of the activities of the Department of Religious Education and Catechism, established under the Moscow Patriarchate in Russia. The head of this department, hegumen Ioan Ekonomtsev at the Episcopal Synod (1994), criticized courses in religious studies and history of world religions taught at Russian universities. His criticism was directed mainly at the phenomenon of the particular discontinuity and lack of integration of these courses. In particular, attention was drawn to the fact that although these courses taught historical information, general principles, practices and ethical views of religion, the liturgical life, which, according to the Hegumen, is the source of all of the above, was ignored. D. Sutton called the phenomenon he encountered in the UK a phenomenon of ,accounting mentality”. This way of material presentation encourages teachers to impart knowledge in details so that it is easily perceived. This incorrect approach, in his opinion, has far-reaching consequences - on the one hand, such partially simplified material distorts the real state of the subject under study, and on the other, it does not allow students to develop critical and interpretative skills. D. Sutton notes that

talking about Christianity as the source of historical, cultural and aesthetic influences, in essence, means emasculating the very essence of the subject - the Christ-centered and ecclesial vision of salvation (Satton, 2003).

In France the situation in is somewhat different. The dangers of fundamentalism, on the one hand, and the oblivion by young people of the Christian roots of a large part of French culture, on the other, prompt everyone indifferent to this situation to seek a solution. It is remarkable that exactly when Christian democracy had the greatest influence in France (1946) it was proclaimed that the IV Republic was a secular state. Already nowadays, the Ministry of National Education is seriously considering options for renewing the teaching of the foundations of religion, since France has faced with a kind of amnesia of the youth who being cut off from its religious and cultural roots risk eventually to become alien to their civilization.

Another aspect of this state of affairs is the inability, to one degree or another, to understand and communicate with civilizations that, as a result of globalization processes and demographic changes, turned out to be very close, literally became neighbors on the same staircase - people of different faiths: Christians, Muslims, Jews etc. In this perspective, it becomes clear that there is an withdraw the study of the phenomenon of religion from a secularized state, which leads to not entirely positive results regarding a society that would go the other way. The ideas presented by F. Surman seem to be appropriate when he wites that.

The ideas that F. Surman puts forward when writing that

the expulsion of religious studies outside the walls of rational and politically controlled broadcasting of knowledge causes further pathologization of this sphere instead of its healing... The objective and deep knowledge of the Holy Scriptures, 
as well as their own traditions, inspires a significant proportion of young people to hesitate the wardship of the fanatical (Siuremen, 2003).

If the approach that actively promotes a certain system of views regarding children and youth does not cause resistance from the majority of society, then the case of the same propaganda regarding the adult population is not so simple. After all, if some will maintain positions of active influence on the worldview of citizens of the state, others will stand on the position of only presenting facts objectively, leaving adults the right to draw conclusions themselves both regarding reality and their development.

When analyzing these two approaches, it is safe to say that the latter is more hypothetical and theoretical than the one that would be implemented in real life. It is not even a case of the examples of gross manipulation of human consciousness through the media of various political forces, or of numerous multinational commercial companies with their obsessive advertising and the use of various psychosocial techniques to increase sales of their goods. In this case, we focus on those things that often do not fall into the field of view of human consciousness. An accurate illustration of this phenomenon is K. Mannheim's words on Marxism:

In the fight against its opponent - the bourgeoisie - Marxism again reveals that there is no pure theory in history and politics ... behind each theory there are certain aspects of the vision inherent in certain groups... this phenomenon - thinking, by social vital interests - Marx calls ideology (Mannhaim, 2008).

Indeed, it is difficult to disagree with the fact that the perception of any human person is significantly influenced by the socio-cultural environment. Marx just used it politically. This phenomenon of the existence of the individual in the space of ideology, in our opinion, emphasizes this kind of position of the state, where it is eliminated from the formation of ideology, freeing up space for the formation of an alternative ideology, which, in turn, can be both positive and negative, where there can be no assurance that alternative ideology will harmonize with the anthropological and transcendental-axiological dimensions of human being. Hereof conclusion follows that the state, as an institution, called upon to ensure socio-economic stability and conditions for transcendental-meaningful development of its citizens, is obliged to shape their correct socio-philosophical habitat. An environment that would be guided in its activity by high moral and ethical principles and ideals of the axiological dimension of being.

Of course, the situation of impossibility of removing the state from the education of its citizens leads to an understanding of its deeply anthropological mission, and this leads to a desire for a deep understanding of the mystery of the human individual. Such a need for an anthropological orientation of the authorities activity encourages the study of the value space of man. In this sense, D. Hildebrand's words are important saying that

the created spiritual personality of man, in essence, is purely objectively oriented to the world of values, and above all to God, the embodiment of all values. The essence of a person can only be understood in view of this orientation and connection (Hildebrand, 2000). 
In the context of our study, the influence of public authorities on the establishment of state-church relations, it seems that in order to ensure the stability and fruitfulness of these relations, the representatives of the state in their existential and ideological dimension should contribute to the ideas propagated by representatives of church structures. Such a peculiar transcendence towards the recognition of the axiological dimension of being with its clear hierarchical structure of values and recognition of the priority, basically, of spiritual values, even in the political dimension of being, gives great hope for the successful realization of not only creative and constructive relations with representatives of the church but successful implementation of positive plans in the political dimension. Successful will be a statesman who is aware of the tasks of his government, as well as those from whom he received power and to whom he should serve. In a democratic state, it is the will of the people that gives the government legitimacy. A conscientious elect should also understand the responsibility that falls on his shoulders. If the elect is a believer, then he must also be aware of his place in the axiological power structure of being, he must know that he is simply an instrument in the hands of the true ruler. With this awareness, one will never move to usurp power and use the latter for personal gain.

The agreements between the Polish government and the bishop of the Roman Catholic Church, which gave the church representatives many rights, can be considered significant. The agreement itself was drawn up in 1950, and it is notable that it was not a new concordat, since the pope did not sign it. The agreement was accepted by the bishops of the Roman Catholic Church in Poland. According to this agreement, the Polish Catholic Church maintained contact with the pope, who was recognized as the highest authority in the church in matters pertaining to church jurisdiction, moral aspects of life and the dogmatic truths of the faith. The recognition by the state of religious freedom did not limit the authority of the pope in the three areas listed above only, while in other cases the bishops should be guided by the interests of the state. The latter, in turn, also went towards the church, as it gave a guarantee of stability and invariance of the modern system of religious education in school. An interesting form of cooperation in this area was that representatives of both education and church authorities had to participate jointly in the implementation of the religious education program and the appointment of inspectors to monitor the progress of religious education. Moreover, religion teachers were given equal rights with other teachers, which consequently affected wages. An eloquent example of the desire of the state to meet the church was that in places where there were schools without religious education, parents were given the opportunity to send their children to schools where religion was taught.

Constructive cooperation between the church and the state was not limited to the sphere of education, it penetrated into many other spheres of social life. Thus, students of religious schools were granted deferrals from military service, and and even more - clergy and monks were generally released from military service. It should also be noted that priests were always present in hospitals, military units and prisons. The Church, for its part, supported a state for such a wise position. As O. Bogolepov notes,

for maintaining the connection with the Holy See and the current internal structure of the Church, for the possibility of open worship and continued (even if limited) educational and charitable activities, the bishop of the Polish Church promised obedience to the new system, to urge the population to support its intensive work and criticize hostile activity of the clergy (Bogoliepov, 1958). 
In addition to the influence of nation-wide ideology, every member of society is in one way or another influenced by certain events, especially the resonant ones, that take place in their life. In this case, much depends on the individual responsible for shaping the interpretation of events. In other words, it is the moral priorities of the interpreter and the purpose with which one implements it that will be very important for shaping public opinion about an event. A society in which there is an awareness of the primacy of the human person over society will always oppose the perception of totalitarian-type ideologies. It is also worth mentioning the phenomenon, which in a certain way can be associated with religious structures and which in some ways resembles a totalitarian approach to reality. We mean a situation where religion is ,perceived as a fundamental basis that divides people into 'friends' and 'strangers"' (Farxitdinova, 2011). The consequence of this state of things will be an increase in tension within society which will in no way fit either the goals of the state or the church. It is in this perspective that another direction emerges for the actions of state authorities, which should guard the religious freedom of their citizens, without exerting in the legislative and other dimensions the advantages of any one religious group. In the context of Ukraine, the actualization of this principle will mean, at the very least, the non-interference of public authorities in the process of identifying one of the denominations of Ukrainian Christianity as the main denomination, with the appropriate involvement of public funds for the development of it solely, that further threatens the use of the latter in mercantile-ideological interests by one or another political force. Public authorities should stand for the peaceful coexistence of these denominations and other religious communities and use various means of influence to prevent the creation of religious extremism in our country. Since in both the socio-philosophical and religious perspectives the society is not yet perfect, the state, according to K. Bart,

has a task in the world not yet saved by the Church, to worry - within the limits of human reason and human capacity, in the case of danger and use of force - about law and freedom (Bart, 2006).

\section{CONCLUSIONS}

Thus, it is difficult to overestimate the role of public authorities in establishing legal relations with the church. The fact is that the teachings of the church on the basic principles of life have been unchanged for centuries. The church has always stood guard over the observance of natural human rights. The essence of its activity was preaching high standards of transcendental-spiritual dimension and taking care of observance of moral and ethical principles in the life of society. In an ideal scenario the state should build its activities in accordance with high moral and ethical principles. But in reality, there are often distortions in its functioning, the last negative poles of which are a totalitarian approach to governing the state and an approach whereby the state actually shies away from leadership, freeing up space for the influence of other, often not entirely positive factors. Despite the fact that representatives of the church structure are always ready to build constructive relations with the state, it is the state authorities that have a great responsibility for establishing such relations and their approval. The source, the engine of their construction should be the awareness of state authorities of their calling and responsibility. Properly understanding their calling, government officials can have a significant positive effect on the development of legal relations in the church dimension of being. One of the priority spheres of their 
activity can be considered educational, legal and religious dimension of the state. In all of these spheres, with a prudent, wise approach, considerable success can be expected in building strong and complementary relationships with the church as an institution-representative of the transcendental-axiological dimension of being.

\section{REFERENCES}

Appeal from the leaders of the Christian churches of Ukraine to legislators and the public regarding the proposal to introduce new ways of registering individuals in Ukraine. (2008). Socially oriented documents of the Ukrainian Greek Catholic Church (1989-2008). Lviv: Publishing house of Ukrainian Catholic University.

Bart, K. (2006). Justification and law. Moscow:St. Andrews's Biblical Theological Institute.

Blihar, V. (2013). State-Church Relations as Explication of the Dichotomy of Power and Society in European Philosophy: A Monograph. Lviv: LvDUVS.

Bogolepov, A. (1958). Church under the rule of communism. Munich.

Dore, D. (2001). The Spirit of Europe: Lecture by Monsignor Joseph Dore at the Catholic University of Budapest. ,Communion: International Theological Journal” No. 3.

Farkhitdinova, O. (2011). Christian ethics, secular morality and secular law as scenarios of modern religiosity. The Social Doctrine of the Church and the Present: Materials of the International Scientific and Practical Conference, May 12-13, 2011 Orel.

Hildebrand, D. (2000). Metaphysics of communication. St. Petersburg: Aletheia.

Humboldt, von W. (2009). Positive and negative state. Liberalism: an anthology. Kyiv: Smoloskyp.

Isaev, A. (2011). Prospects for the development of socio-political partnership between government body of state authority and the Russian Orthodox Church: regional aspect. The Social Doctrine of the Church and the Present: Proceedings of the International Scientific and Practical Conference, May 12-13, 2011 Orel.

Mannheim, K. (2008). Ideology and Utopia. Kiev: Duh i Litera.

Parsons, V. (2006). Public Politics: An Introduction to the Theory and Practice of Politics Analysis. Kiev: Publishing House of Kyiv-Mohyla Academy.

Suremen, F. de. (2003). Teaching the basics of religion in secular education system of France. „Duh i Litera”, 11/12.

Sutton, D. (2003). What attitudes affect the educational situation in the country?, „Duh i Litera”, $11 / 12$.

Vloet, J. van der. (1994). The anthropological significance of Sunday. „Communion: International Theological Journal” No. 4.

DOI: $10.7862 /$ rz.2020.hss.26

The text was submitted to the editorial office: December 2019.

The text was accepted for publication: September 2020. 